компетентності майбутнього вихователя дошкільного закладу. Більшість опитаних вихователів (62\%) педагогічні ситуації на заняттях використовують час від часу, а $9 \%$ - майже ніколи їх не застосовують. Наявна недооцінка моделювання педагогічних ситуацій як ефективного засобу професійного становлення майбутнього вихователя; відсутність єдиного підходу до структурування змісту професійно важливих знань, класифікацій методичних прийомів і педагогічних технологій, що застосовуються на заняттях у вищий педагогічній школі.

Порівнюючи результати констатувального і формувального експериментів, ми переконалися в ефективності запропонованої нами програми занять, на яких використовувалися педагогічні ситуації, створюють необхідні умови задля підвищення якості знань студентів. Ефективним методом у формуванні комунікативних умінь висловлювати власні думки $\epsilon$ «Мозкова атака»- методи колективного розв'язання проблеми. Перед студентами ставилася окрема ситуація, яка вимагала обговорення й виявлення можливих шляхів її розв'язання. Кожна версія розглядалася окремо, обов'язково виокремлювалися переваги та недоліки. Кінцевий результат - обиралася найбільш вдала думка.

Отримані результати пояснюються низкою труднощів, зумовлених як соціальноекономічними, так і суб'єктивними чинниками навчально-виховного процесу педагогічного ВНЗ. 3-поміж них: недостатнє професійне педагогічне спрямування навчальних курсів кожного зі складників підготовки, підвищена вага фундаменталізації змісту підготовки, відсутність міжпредметної координації і співпраці у становленні цілісної особистості майбутнього вихователя; неусвідомлення суб'єктами професійної підготовки (викладачами і студентами) професійної компетентності як системної якості; недооцінювання засобів моделювання педагогічних ситуацій на всіх етапах і напрямах професійної підготовки, відсутність широкого вибору майбутніми вихователями траєкторій професійного й особистісного розвитку. Перспективу роботі ми вбачаємо у розробленні професійних ситуацій та завдань, спрямованих на формування проектних умінь студентів.

\title{
Література
}

1. Дубасенюк О. А. Професійно-педагогічні задачі: типологія та технологія розв'язання : [навч. посіб. для студентів вищих навчальних закладів]/ О. А. Дубасенюк, О. В. Вознюк. - Житомир : Вид-во ЖДУ ім. І. Франка, 2010. - 272 с. 2. Луговий В. Європейська концепція у вищій школі та проблеми іiі реалізації в Україні компетентнісного підходу / В. Луговий // Реалізація європейського досвіду компетентнісного підходу у вищій школі України: [матеріали методологічного семінару]. - К. : Педагогічна думка, 2009. - С. 5-10. 3. Освітні технології: [навч.метод. посіб. / за заг. ред. О. М. Пєхоти]. - К. : А.С.К., 2001. - 256 с. 4. Сериков В. В. Личностно ориентированное образование: поиск новой парадигмы : [монография] / Владислав Владиславович Сериков. - М. : Логос, 1998. - 350 с.

УДК 378 : 005.6

Лариса Савченко

\section{АНАЛІЗ НОРМАТИВНИХ ДОКУМЕНТІВ ПІДВИЩЕННЯ ЯКОСТІ ОСВІТИ МАЙБУТНІХ УЧИТЕЛІВ ТЕХНОЛОГІЇ І КРЕСЛЕННЯ ЗАСОБАМИ ПЕДАГОГІЧНОЇ ДІАГНОСТИКИ}

Савченко Л. О. Аналіз нормативних документів підвищення якості освіти майбутніх учителів технології і креслення засобами педагогічної діагностики.

У статті проаналізовано навчальні плани, освітні стандарти щодо підготовки 
майбутнього вчителя технології і креслення до педагогічної діагностики якості освіти. Останнім часом спостерігаються значні зміни у напрямку підготовки майбутнього вчителя, але мало уваги приділяється питанню підготовки майбутнього вчителя технологічної освіти до педагогічної діагностики у процесі вивчення педагогічних і спеціальних дисциплін.

Ключові слова: якість освіти, педагогічна діагностика, стандарт, навчальний план, підготовка вчителя.

Савченко Л. А. Анализ нормативных документов повышения качества образования будущих учителей технологии и черчения средствами педагогической диагностики.

В статье проанализировано учебные планы, образовательные стандарты подготовки будущего учителя технологии и черчения к педагогической диагностике качества образования. В последнее время наблюдаются значительные изменения в направлении подготовки будущего учителя, но мало внимания уделяется вопросу подготовки будущего учителя технологического образования к педагогической диагностике в процессе изучения педагогических и специальных дисциплин.

Ключевые слова: качество образования, педагогическая диагностика, стандарт, учебный план.

Savchenko L. O. The analysis of normative documents as for improving education of future technology teachers and draft through pedagogical diagnostics facilities

The article analyzes curricula, educational standards of training future technology and drawing teacher for pedagogical diagnostics of quality of education. Considerable changes towards training a future teacher have been recently observed, but little attention has been paid to training a future technology teacher for pedagogical diagnostics in the process of studying special disciplines.

Key words: quality of education, pedagogical diagnostics, standard, curriculum.

Нові вимоги для європейського виміру педагогічної освіти обгрунтовано в доповіді Європейської комісії «Про конкретні майбутні завдання для освіти та професійної підготовки у Європі» (Стокгольм, 2001 р.), що містить пропозиції стосовно спільних дій країн-членів у галузі освіти до 2010 р. Ця доповідь стала першим документом, де запропоновано стратегію розвитку національних освітніх політик, зокрема такі спільні цілі: 1) підвищення якості й ефективності систем освіти та підготовки у країнах $\mathrm{CC}$; 2) спрощення доступу до всіх форм освіти впродовж життя; 3)посилення відкритості систем освіти та підготовки сучасного світу. Унаслідок аналізу з'ясовано, що спільні принципи сформульовані розробниками крізь призму нового бачення професії вчителя, оскільки в умовах загальноєвропейської інтеграції професія вчителя змінюється й набуває нових характеристик. Як зазначено в документі, педагогічний фах має стати: а) висококваліфікованою професію, б) професією, якої необхідно навчатися впродовж усього життя; в) мобільною професією; г) професією, що базована на партнерстві.

За словами директора Центру тестових технологій і моніторингу якості освіти I. Лікарчука, одна 3 проблем пов'язана 3 тим, що нині в Україні одні й ті самі органи управління освітою керують галуззю і контролюють їі якість [3]. Саме через це більшість реформаторських заходів у системі освіти не досягає мети, призводячи до неефективного використання бюджетних і приватних коштів, знецінюючи сутність і зміст освітньої діяльності. Управління якістю освіти на різних рівнях організації 
розкрито у працях М. Альберта, М. Вебера, М. Вудкока, М. Мескона, С. Паркінсона, Т. Пітерса, Ф. Тейлора, П. Уотермана, А. Файоля, М. Хедоурі, Л. Якоккі та інших авторів. На необхідності пошуку умов, що оптимізують якість професійної підготовки майбутніх учителів, зосереджують увагу А. Богуш, Е. Карпова, Л. Кондрашова, А. Кузьмінський, В. Луговий, О. Ляшенко, Н. Ничкало.

Mema cmammi. Проаналізувати навчальні плани, стандарти щодо підготовки майбутнього вчителя технології і креслення до педагогічної діагностики якості освіти. Останнім часом спостерігаються значні зміни у напрямку підготовки майбутнього вчителя, але недостатньо уваги приділяється питанню підготовки майбутнього вчителя технологічної освіти до педагогічної діагностики у процесі вивчення педагогічних i спеціальних дисциплін. Постає проблема виявлення потенційних можливостей педагогічних та спеціальних дисциплін у підготовці майбутнього вчителя технології і креслення до педагогічної діагностики якості освіти.

Основним результатом досліджень 3 аналізу педагогічної освіти Європи стало формулювання експертами визначення поняття «курикулум педагогічної освіти» на підставі трактувань, що найчастіше використовують у сучасній педагогічній теорії і практиці європейських країн. Відомо, що в зарубіжній педагогіці запропоновано понад 400 дефініцій курикулуму, нині так називають усі предмети та їх зміст, що викладають у навчальному закладі.

Відповідно до документів європейських освітніх організацій поняття «курикулум» означає «план для навчання», що складається з інтегрованого, логічно послідовного, взаємопов'язаного комплексу навчальних ситуацій і містить: чіткі мету та завдання навчання; зміст навчання; методики навчання й викладання; поведінкові кліше, що формують культуру навчання; навчальні матеріали; процедури моніторингу та оцінювання навчання студентів і викладацької діяльності педагогів; структуру навчального процесу (робочу навчальну програму), механізми адаптації до індивідуальних потреб і попереднього освітнього досвіду студентів [4].

Окрім того, науковці дійшли висновку, що конструювання курикулуму педагогічної освіти й підготовки потребує: 1) ретельного аналізу професійних ролей учителів, які суттєвою мірою залежать від культурного та соціального контексту; професійних функцій учителів (викладання, виховання, консультування, оцінювання, упровадження інновацій, проведення досліджень тощо); кваліфікацій, необхідних для виконання окреслених професійних ролей і функцій; 2) адаптації моделей здобуття таких кваліфікацій; 3) орієнтації навчальних програм на професійні ролі, функції та кваліфікації.

Згідно із завданнями Болонського процесу кожна навчальна програма має відповідати суспільним вимогам, сприяти працевлаштуванню, виховувати громадянські якості, бути схваленою науковим співтовариством і вирізнятися прозорою структурою, що надає змогу комбінувати іiі 3 програмами інших університетів, забезпечуючи мобільність студентів, визнання результатів їхнього навчання за кордоном.

Навчальна програма повинна бути зрозумілою і привабливою для численної кількості вітчизняних i зарубіжних студентів. Додатковими критеріями якості навчальної програми, на думку фахівців, є правильний вибір шляхів досягнення навчальних цілей, а також узгодженість окремих елементів. Таке розуміння якості освітньої діяльності університетів із конструювання курикулумів у межах формування європейського простору вищої освіти відображено в документі «Стандарти й методичні рекомендації забезпечення якості в загальноєвропейському просторі вищої освіти» («Standards and Guidelines for Quality Assurance in the European Higher 
Education Area») [5].

Отже, провідні європейські експерти в галузі вищої освіти розробили й представили до запровадження фундаментальні принципи вдосконалення структури i змісту навчальних програм, їх реалізації: обгрунтування необхідності програми (з'ясування потреб); повний i чіткий опис програми із зазначенням напряму підготовки та спеціалізації; вивчення результатів навчання, що відповідають профілю програми, у компетентнісному вимірі; коректний розподіл кредитів за структурними одиницями програми в межах Європейської кредитно-трансферної системи (СКТС); добір методів навчання й оцінювання, що узгоджені з цілями програми.

Реалізація представлених принципів передбачає безперервний процес забезпечення якості, що грунтований на усвідомленні його значущості всіма зацікавленими учасниками. 3 огляду на ці принципи варто констатувати, що основою для розроблення, запровадження й реалізації програм слугує компетентнісний підхід [2].

Основу для оцінювання якості вищої освіти та професійної підготовки, а також якості діяльності ВНЗ становлять стандарти вищої освіти. До стандартів вищої освіти України належать: державний стандарт, галузеві стандарти, стандарти ВНЗ.

Для високоякісного контролю за всіма видами навчальної діяльності студентів розроблено програму педагогічної діагностики якості освіти в умовах кредитномодульної системи організації навчального процесу. Задля окреслення завдань педагогічного експерименту проаналізовано навчальні плани різних факультетів Криворізького педагогічного інституту ДВНЗ «Криворізький національний університет».

Нижче продемонстровано приклад зі стандарту професійної підготовки вчителя технологій і креслення. Виробничі функції, типові завдання діяльності та вміння, якими повинен володіти випускник Криворізького педагогічного інституту ДВНЗ «Криворізький національний університет».

Таблиия 1

Виробничі функції, типові завдання діяльності, уміння, якими повинні володіти випускники технолого-педагогічного факультету

\begin{tabular}{|c|c|c|}
\hline $\begin{array}{c}\text { Зміст виробничої } \\
\text { функції }\end{array}$ & $\begin{array}{c}\text { Назва типового } \\
\text { завдання }\end{array}$ & Зміст уміння \\
\hline \multirow[t]{6}{*}{$\begin{array}{l}\text { Проведення всіх } \\
\text { форм занять у у } \\
\text { середніх навчально- } \\
\text { виховних закладах. }\end{array}$} & Планування занять. & $\begin{array}{l}\text { Скласти план проведення й конспект } \\
\text { занять із використанням навчально- } \\
\text { методичних документів і навчально- } \\
\text { методичної літератури. }\end{array}$ \\
\hline & & $\begin{array}{l}\text { Урахувати психологічні особливості } \\
\text { учнів у ході підготовки, планування та } \\
\text { проведення занять. }\end{array}$ \\
\hline & Проведення занять. & $\begin{array}{l}\text { Використовувати знання за фахом і } \\
\text { спеціалізацією під час проведення } \\
\text { занять. }\end{array}$ \\
\hline & & $\begin{array}{l}\text { Застосовувати психолого-педагогічні } \\
\text { знання в процесі проведення занять. }\end{array}$ \\
\hline & & $\begin{array}{l}\text { Використовувати дидактичні засоби } \\
\text { навчання, технічні засоби навчання та } \\
\text { iнші навчальні посібники. }\end{array}$ \\
\hline & & Отримувати і використовувати науково- \\
\hline
\end{tabular}




\begin{tabular}{|c|c|c|}
\hline $\begin{array}{c}\text { Зміст виробничої } \\
\text { функції }\end{array}$ & $\begin{array}{c}\text { Назва типового } \\
\text { завдання }\end{array}$ & Зміст уміння \\
\hline & & $\begin{array}{l}\text { технічну інформацію за фахом для } \\
\text { ведення занять. }\end{array}$ \\
\hline & $\begin{array}{l}\text { Контроль знань, } \\
\text { набутих учнями, } \\
\text { студентами- } \\
\text { слухачами. }\end{array}$ & $\begin{array}{l}\text { Складати контрольні завдання, тести } \\
\text { тощо для перевірки знань учнів, } \\
\text { використовуючи навчально-методичні } \\
\text { матеріали. }\end{array}$ \\
\hline & & $\begin{array}{l}\text { Використовувати ЕОМ для проведення } \\
\text { контрольних заходів. }\end{array}$ \\
\hline \multirow[t]{3}{*}{$\begin{array}{l}\text { Навчально- } \\
\text { методична робота. }\end{array}$} & $\begin{array}{l}\text { Забезпечення } \\
\text { незалежного } \\
\text { методичного рівня } \\
\text { знань. }\end{array}$ & $\begin{array}{l}\text { Скласти робочий план, програми } \\
\text { дисциплін та інші навчально-методичні } \\
\text { документи. }\end{array}$ \\
\hline & & $\begin{array}{l}\text { Використовувати методи навчання } \\
\text { технології, креслення, комп'ютерної } \\
\text { графіки для проведення всіх форм } \\
\text { занять. }\end{array}$ \\
\hline & $\begin{array}{l}\text { Методичне } \\
\text { забезпечення } \\
\text { самостійної роботи } \\
\text { учнів, студентів- } \\
\text { слухачів. } \\
\end{array}$ & 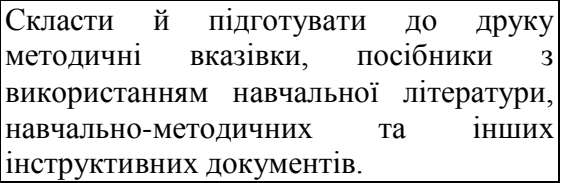 \\
\hline \multirow[t]{4}{*}{$\begin{array}{l}\text { Навчально- } \\
\text { громадське } \\
\text { виховання } \\
\text { студентів. } \\
\end{array}$} & $\begin{array}{l}\text { Організація та } \\
\text { проведення виховної } \\
\text { роботи. }\end{array}$ & $\begin{array}{lcc}\text { Планувати } \quad \text { виховну роботу } & \text { та } \\
\text { виконувати іiі в навчальному процесі. } & \end{array}$ \\
\hline & & $\begin{array}{l}\text { Планувати } \quad \text { позанавчальну } \\
\text { роботу та впроваджувати їі. }\end{array}$ \\
\hline & & $\begin{array}{l}\text { Організовувати позанавчальні виховні } \\
\text { заходи } 3 \text { використанням технічних та } \\
\text { iнших засобів. }\end{array}$ \\
\hline & & $\begin{array}{l}\text { Вивчати ефективність виховної роботи й } \\
\text { рівень вихованості учнів. }\end{array}$ \\
\hline
\end{tabular}

Відомості, подані в таблиці, засвідчують, що в освітньо-кваліфікаційній характеристиці майбутнього фахівця зазначено не всі аспекти. На наш погляд, бракує опису вмінь володіти проектною діяльність, що $є$ основною формою роботи вчителя технологій і креслення, не схарактеризовані вміння прогнозувати результати навчання учнів, поза увагою залишається педагогічна діагностика.

Освітня діяльність студента ВПНЗ відображена в освітньо-кваліфікаційній характеристиці. Так, освітньо-кваліфікаційна характеристика випускника Криворізького педагогічного інституту ДВНЗ «Криворізький національний університет» - нормативний документ, що узагальнює зміст вищої освіти, тобто відображає мету вищої освіти та професійної підготовки, описує місце фахівця в структурі галузей економіки держави й вимоги до його компетентності, інших соціально важливих властивостей і якостей. Цей стандарт є складником стандартів вищої освіти, де систематизовано вимоги з боку споживачів до змісту вищої освіти. Порівняння нормативної і варіативної частин навчальних планів Криворізького 
педагогічного інституту ДВНЗ «Криворізький національний університет» технологопедагогічного, природничого та фізико-математичного факультетів надає підстави стверджувати, що в межах одного вищого навчального закладу передбачено різні години на однакові цикли підготовки.

Таблиия 2

Аналіз навчальних планів підготовки бакалаврів у педагогічній вищій школі (години / кредити ECTS)

\begin{tabular}{|l|c|c|c|}
\hline \multicolumn{1}{|c|}{ Назви циклів } & \multicolumn{2}{|c|}{$\begin{array}{r}\text { Факультети Криворізького педагогічного } \\
\text { інституту ДВНЗ «КНУ» }\end{array}$} & $\begin{array}{c}\text { Фізико- } \\
\text { матема- } \\
\text { тичний }\end{array}$ \\
\cline { 2 - 4 } & $\begin{array}{c}\text { Технолого- } \\
\text { педагогічний }\end{array}$ & Природничий & 648 \\
\hline $\begin{array}{l}\text { Цикл гуманітарної й соціально- } \\
\text { економічної підготовки (нормативна } \\
\text { частина). }\end{array}$ & 648 & 648 & 396 \\
\hline $\begin{array}{l}\text { Цикл гуманітарної й соціально- } \\
\text { економічної підготовки (варіативна } \\
\text { частина). }\end{array}$ & 540 & 396 & 1620 \\
\hline $\begin{array}{l}\text { Цикл природничо-наукової } \\
\text { підготовки (нормативна частина). }\end{array}$ & 1350 & 1368 & 396 \\
\hline $\begin{array}{l}\text { Цикл природничо-наукової } \\
\text { підготовки (варіативна частина). }\end{array}$ & 162 & 666 & 2088 \\
\hline $\begin{array}{l}\text { Цикл професійної та практичної } \\
\text { підготовки (нормативна частина). }\end{array}$ & 4824 & 3780 & 2952 \\
\hline $\begin{array}{l}\text { Цикл професійної та практичної } \\
\text { підготовки (варіативна частина). }\end{array}$ & 1008 & 1710 & \\
\hline
\end{tabular}

Згідно 3 таблицею цикл природничо-наукової підготовки (нормативна частина) на фізико-математичному факультеті перевищує близько 300 годин, а на технолого-педагогічному та природничому факультеті збігається (1350 годин). Цикл професійної й практичної підготовки (нормативна частина) на фізико-математичному факультеті становить 2088 годин, а на технолого-педагогічному - 4824, на природничому - 3780 (різниця - 2736 годин). У варіативній частині циклів підготовки теж зафіксовано різні підходи до розподілу годин. Цикл природничо-наукової підготовки (варіативна частина) на фізико-математичному факультеті перевищує на 234 години кількість годин на технолого-педагогічному факультеті, на природничому - на 334 години порівняно з технолого-педагогічним факультетом.

Варто звернути увагу на цикл професійної й практичної підготовки (варіативна частина), де констатовано серйозну розбіжність годин. Так, на фізико-математичному факультеті це 2952 години, технолого-педагогічному - 1008 годин (розбіжність - 1944 години), із природничим факультетом - 1242 години. На нашу думку, такі розбіжності в розподілі годин є основною проблемою щодо надання якісної освіти. Аналіз годин із нормативної та варіативних частин на факультетах зі спорідненими циклами фахових дисциплін засвідчив різні підходи до стандартів освіти, а отже, і до змісту навчання у вищій педагогічній школі. За результатами аналізу планування годин згідно 3 навчальними планами, можна стверджувати, що обсяг змісту освіти зі споріднених спеціальностей різний.

У ході дослідження проаналізовано навчальні плани технолого-педагогічних факультетів вищих педагогічних закладів України: ДВНЗ «Донбаський державний 
педагогічний університет», Уманського педагогічного університету імені Павла Тичини, Криворізького педагогічного інституту ДВНЗ «Криворізький національний університет».

Зосередимо увагу на тому, що однакові факультети мають різні години в навчальних планах із нормативної частини. Так, цикл гуманітарної й соціальноекономічної підготовки (нормативна частина) в Уманському педагогічному університеті становить 1404 години, у Криворізькому педагогічному інституті - 648 годин (різниця - 756 годин), із ДВНЗ «Донбаським державним педагогічним університетом»- 648 годин. Цикл природничо-наукової підготовки (нормативна частина) у Криворізькому педагогічному інституті передбачає 270 годин, тобто більше ніж в Уманському педагогічному університеті й менше на 620 від ДВНЗ «Донбаський державний педагогічний університет». Цикл професійної та практичної підготовки (нормативна частина) засвідчує наявність різних підходів до розподілу годин. Так, у Криворізькому педагогічному інституті заплановано 4824 години, в Уманському педагогічному університеті - 3348 годин (різниця - 1476 годин), наявна невелика різниця порівняно 3 ДВНЗ «Донбаський державний педагогічний університет»- 666 годин.

У варіативних частинах циклів підготовки фахівців зафіксовано очевидну розбіжність годин між педагогічними вищими навчальними закладами. Цикл гуманітарної й соціально-економічної підготовки (варіативна частина) та цикл природничо-наукової підготовки (варіативна частина) у ДВНЗ «Донбаський державний педагогічний університет» відсутні, натомість в Уманському педагогічному університеті він становить усього 54 години. Цикл професійної і практичної підготовки (варіативна частина) у Криворізькому педагогічному інституті передбачає 1008 годин, у Донбаському педагогічному університеті - 468 годин, в Уманському педагогічному університеті - 405 годин (540 годин і 603 години різниці). Відомості, представлені в таблиці, переконливо доводять наявність різних підходів до планування годин у навчальних закладах, що зумовлює різні підходи до фахової підготовки майбутнього вчителя технологій і креслення. Постає нагальна потреба в розробленні стандарту підготовки бакалавра та спеціаліста в освітній кваліфікації вчителя технологій і креслення.

Отже, зафіксовано низку особливостей планування годин на одному й тому ж факультеті в різних педагогічних вищих навчальних закладах. Отримані дані вмотивували логіку побудови педагогічного експерименту.

Педагогічне діагностування якості знань професійної підготовки майбутніх педагогів передбачає обстеження, спостереження й аналіз процесу навчання, надає змогу одержувати та використовувати інформацію про адекватність педагогічних технологій, форм, методів і засобів; корегувати навчальний процес.

На якість знань студентів впливають такі чинники:

1) рівень і якість довишівської підготовки абітурієнтів;

2) якість освітніх стандартів, управління якістю освіти;

3) зміст навчальних планів і програм;

4) якість організації навчального процесу та науково-методичне забезпечення;

5) матеріально-технічна база, морально-психологічний клімат;

6) педагогічна компетентність i педагогічна майстерність професорськовикладацького складу.

Задля формування змісту освіти важливим видається виконати низку завдань: гармонізація профільних дисциплін і розподіл часу з огляду на їхню значущість у професійній підготовці майбутніх учителів технології; варіативність навчальних програм; перехід до індивідуальних форм i технологій навчання 3 широким 
використанням інноваційних технологій.

Для перевірки висловлених у процесі дослідження та сформульованих у гіпотезі припущень проведено педагогічний експеримент. На початку дослідження окреслено мету реалізації педагогічної діагностики підвищення якості освіти:

1) забезпечення якості освітньої підготовки майбутніх педагогів, визначення ступеня їхньої педагогічної компетентності, рівня підготовки до практичної діяльності відповідно до вимог галузевих стандартів- освітньо-кваліфікаційної характеристики та освітньо-професійної програми тощо;

2) одержання й використання інформації про адекватність педагогічних технологій, методів, форм і засобів навчання;

3) корекція змісту навчання, вибір ефективних педагогічних технологій, форм навчання, самостійної роботи студентів, контролю результатів аудиторної та позааудиторної роботи студентів тощо;

4) упровадження в навчально-виховний процес інновацій, авторських методик викладання, що екстраполюють професійну діяльність на якісно новий рівень.

Згідно 3 Державним стандартом освітньої галузі «Технологія», змістом технологічної освіти передбачено послідовне включення студентів в усі етапи цілісного процесу проектування і виготовлення виробів.

У підготовці майбутнього вчителя технології і креслення важливе місце посідає формування у нього власного досвіду проектної діяльності. Навчитися створювати проекти студенти можуть у процесі підготовки, а саме під час вивчення спеціальних дисциплін. В основу реалізації змістових ліній освітньої галузі «Технологія» покладено проектно-технологічну діяльність, яка інтегрує всі види сучасної діяльності людини: від появи творчого задуму до реалізації готового продукту [1].

Проведення таких занять дозволяє залучити майбутніх учителів технології і креслення до всіх етапів проектної діяльності, що сприяє глибшому засвоєнню навчального матеріалу, формуванню творчих здібностей, поглибленню якості освіти.

Аналіз дидактичної частини підготовки бакалавра показав, що проектна діяльність не відображена, на цикли професійно-педагогічної підготовки виділено мало годин, а звідси і недостатній рівень якості освіти. Педагогічну діагностику можна впроваджувати, але без застосування комплексу методик, застосовуючи поодинокі критерії, що унеможливлює якісне обстеження підготовки майбутніх учителів технології і креслення.

Вища педагогічна школа повинна готувати вчителя технології і креслення широкого профілю, проектувальника різноманітних педагогічних методів i методичних прийомів, здатний забезпечити педагогічну підтримку учням, організувати і провести педагогічну діагностику, знайти правильне розв'язання у проблемній педагогічній ситуації.

Звичайно, майбутні вчителі технології і креслення постійно стикатимуться 3 технологією виготовлення того чи іншого виробу, але при цьому необхідно здійснювати творчий підхід до його створення і водночас дотримуватися естетики виробництва і враховувати позитивного впливу на емоційно-чуттєву сферу людини. Відповідно, одним із завдань вищої школи є підготовка спеціаліста, який досконало володіє основами технологічних процесів, виявляє творчу активність і здатний забезпечити послідовне залучення учнів до всіх етапів цілісного процесу проектування і здійснювати педагогічну діагностику.

Упроваджуючи систему педагогічної діагностики в освітній процес педагогічного вишу, потрібно акцентувати увагу на стані навчально-виховного процесу. У системі освіти результати констатуються через певний проміжок часу, 
тому запропоновано аналіз стану навчально-виховного процесу розпочинати 3 вивчення наявності навчально-методичного комплексу до дисциплін професійнопредметного, педагогічного й варіативного циклів, зміст яких містить:

1) навчальну програму;

2) робочу програму;

3) опорний конспект лекцій;

4) розробки для візуального супроводу викладання й вивчення дисципліни (схеми, таблиці, рисунки);

5) навчальні та контрольні тести, збірники завдань, задач;

6) методичні вказівки й завдання щодо виконання контрольних робіт для заочників;

7) тематику курсових робіт і методичні вказівки до їх виконання;

8) екзаменаційні білети та питання для проведення заліків;

9) пакети комплексних контрольних робіт (завдань) для заміру поточних i залікових знань студентів із дисципліни в процесі іiі викладання й вивчення, а також поточних та залишкових знань (ККР);

10) методичні вказівки щодо організації самостійної роботи студентів із навчальної дисципліни, інструкційні картки, добір планових документів, довідники, кодекси законів тощо;

11) методичні рекомендації щодо використання персональних комп’ютерів (ПК), інших технічних засобів у ході викладання й вивчення дисципліни;

12) пакет чинних законодавчих та інструктивних документів стосовно навчальної дисципліни;

13) перелік навчальної й наукової літератури, наявної в бібліотеці інституту та доступної для використання під час викладання й вивчення дисципліни;

14) теми дипломних робіт і методичні вказівки до їх виконання й захисту.

Реалізація змін у підходах до технологічної підготовки майбутніх учителів технології i креслення ставить проблему формування професійних умінь, спрямованих не просто на контроль знань та умінь школярів, а на педагогічну діагностику їх діяльності та розвитку. Це значно складніше, ніж традиційна освіта. У такій ситуації очевидним $\epsilon$ те, що першочерговим завданням $\epsilon$ не тільки засвоєння певних знань, умінь, а й формування професійної компетентності майбутнього вчителя технології і креслення, складовою якої $\epsilon$ готовність до педагогічної діагностики. Подальшу свою роботу ми вбачаємо у розробленні тестових завдань із фахових дисциплін.

\section{Література}

1. Концептуальні засади розвитку педагогічної освіти України та їі інтеграції в Європейський освітній простір [Електронний ресурс] / Режим доступу: http://osvita.ua/legislation/Vishya_osvita/3145. - 6 c. - (затверджено наказом МОН № 998 від 31.12.2004). 2. Корсак К. В. Світова вища освіта. Порівняння і визнання закордонних кваліфікацій і дипломів : [монографія] / К. В. Корсак; [за заг. ред. проф. Г. В. Щокіна]. - К. : МАУП-МКА, 1997. - 208 с. 3. Про невідкладні заходи щодо запровадження зовнішнього незалежного оцінювання та моніторингу якості освіти [Текст] : постанова Кабінету Міністрів України від 31 грудня 2005 р. № 1312 // Освіта України. - 2006. - 31 січня. - C. 2. 4. Review of National Curricula and Assessing Digital Competence for Students and Teachers - Digital Skills Working Group, 2010 [Електронний ресурс]. - Режим доступу: http://cms.eun.org/shared/data/pdf/ curricula_review_final_reduced.pdf. 5. Standards Guidance [Электронный pecypc]. - URL: http://www.tda.gov.uk/partners/ittstandards/guidance_08/qts (дата обращения 03.02.2010). 